\title{
PEMBERDAYAAN MASYARAKAT DESA BANARAN, GALUR DALAM PROGRAM PEMANFAATAN DAN PENGOLAHAN HASIL PERTANIAN
}

\author{
Soviyah, Mahasiswa KKN Reguler Divisi XII.A \\ Universitas Ahmad Dahlan Yogyakarta \\ E-mail: soviindrawan@gmail.com
}

\begin{abstract}
Abstrak
Masyarakat di Desa Banaran mayoritas merupakan petani. Dari kegiatan pertanian yang dilakukan banyak limbah hasil pertanian yang dibuang dan tidak diolah serta hasil pertanian yang dijual dalam bentuk bahan mentah. Melihat banyaknya hasil pertanian yang belum diolah secara maksimal, maka program KKN Reguler UAD difokuskan pada pemanfataan dan pengolahan hasil pertanian. Program ini bertujuan memberdayakan masyarakat di tiga pedukuhan untuk memanfaatkan dan mengolah hasil pertanian. Metode pelaksanaan program KKN dilakukan dengan melakukan penyuluhan dan pelatihan dengan praktik langsung kepada masyarakat. Dampak dari kegiatan ini menambah ilmu dan pengetahuan masyarakat dalam hal pemanfaatan dan pengolahan hasil pertanian, diantaranya seperti: 1) Pengolahan limbah sayuran dan kulit buah, 2) Pengolahan Jerami 3) Pengolahan Nata de Leri.
\end{abstract}

Kata kunci: pemberdayaan masyarakat, Banaran, pemanfaatn dan pengolahan hasil pertanian.

\begin{abstract}
Banaran majority community in the village are farmers. From agricultural activities that do a lot of waste disposed of agricultural products and processed and agricultural products are sold in the form of raw materials. Seeing the number of unprocessed agricultural products to the maximum, then the UAD Regular service learning program focused on the utilization of and processing of agricultural products. The program aims to empower communities in three hamlets to utilize and process agricultural products. KKN program execution method is done by counseling and training to the practice directly to the public. The impact of this activity is to increase the knowledge and the knowledge society in terms of utilization and processing of agricultural products, such as: 1) Waste vegetable and fruit peels, 2) Processing Straw 3) Processing Nata de Leri.

Keywords: empowerment, Banaran, utilization and processing of agricultural products.
\end{abstract}




\section{A. PENDAHULUAN}

Desa Banaran terletak di Kecamatan Galur Kabupaten Kulon Progo. Desa ini terletak di wilayah paling selatan dan paling timur diantara desa- desa di Kabupaten Kulon Progo. Secara administratif Desa Banaran memiliki luas wilayah sebesar 901,5 ha dan terdiri dari 13 pedukuhan. Adapun nama-nama pedukuhan dapat dilihat pada tabel I.

Tabel I. Nama Pedukuhan di Desa Banaran Kecamatan Galur

\begin{tabular}{|c|l|l|}
\hline No & \multicolumn{1}{|c|}{ Dusun } & \\
\hline 1 & Dusun I & Jati \\
\hline 2 & Dusun II & Bunder 2 \\
\hline 3 & Dusun III & Bunder 3 \\
\hline 4 & Dusun IV & Bunder 4 \\
\hline 5 & Dusun V & Pundong \\
\hline 6 & Dusun VI & Sidakan \\
\hline 7 & Dusun VII & Kenteng \\
\hline 8 & Dusun VIII & Banaran \\
\hline 9 & Dusun IX & Jalan \\
\hline 10 & Dusun X & Jonggrangan \\
\hline 11 & Dusun XI & Bleberan \\
\hline 12 & Dusun XII & Sawahan \\
\hline 13 & Dusun XIII & Sidorejo \\
\hline
\end{tabular}

Potensi pertanian utama yang telah ditekuni dan dikembangkan oleh penduduk di Desa Banaran adalah pertanian buah semangka, melon dan buah naga. Komoditas pertanian tersebut menjadi komoditas unggulan masyarakat Desa Banaran. Pemasaran produk pertanian tersebut telah berhasil menembus pasar regional maupun nasional. Salah satu area pemasarannya bahkan sudah sampai lintas propinsi seperti ke Jawa Barat dan DKI Jakarta.

Meskipun potensi pertanian di Desa sudah bisa dikatakan baik berikut pemasarannya, namun demikian ada beberapa permasalahan yang dihadapi oleh masyarakat Desa Banaran terkait hal ini. Salah satu permasalahan terkait distribusi ada pada aspek aksesibilitas, yaitu kualitas jalan yang masih perlu pembenahan. Akses jalan satu-satunya untuk jalur distribusi adalah jalan lingkar selatan desa yang kondisinya masih perlu pembenahan. Kondisi jalan yang rusak, dan sangat sempit menghambat akses truktruk pengangkut buah-buahan, terutama saat parkir dan saat loading produk ke atas truk. 
Hal ini menjadi kendala tersendiri karena jalan yang sempit menyebabkan kemacetan lalu lintas ketika proses loading sedang dilaksanakan.

Selain permasalahan pada kualitas akses jalan, terdapat beberapa permasalahan yang ditemukan di Desa Banaran, terutama pada Pedukuhan Jati, Bunder 2, dan Bunder 3. Permasalahan tersebut antara lain sebagai berikut:

1. Kurangnya pengetahuan masyarakat tentang pemanfaatan dan pengolahan hasil pertanian dan limbahnya.

2. Kurangnya fasilitas dari pemerintah maupun dinas pertanian terkait dengan proses pengolahan hasil pertanian dan limbahnya.

3. Kurangnya keterampilan masyarakat untuk mengolah hasil potensi pertanian yang dimiliki.

Peran serta masyarakat dalam pengolahan hasil pertanian dan limbahnya merupakan kesediaan masyarat untuk melaksanakan dan menyukseskan keberhasilan progam pengolahan hasil pertanian dan limbahnya. Dengan peran serta masyarakat yang maksimal, potensi hasil pertanian dan limbah yang dihasilkan akan dapat dimaksimalkan untuk peningkatan kualitas kehidupan masyarakat Banaran. Tanpa adanya peran serta masyarakat, program pengolahan hasil pertanian dan limbahnya tidak akan berhasil, baik itu progam sudah dilaksanakan maupun yang baru direncanakan.

Berkaitan dengan hal ini, mahasiswa KKN UAD melakukan beberapa cara pendekatan kepada masyarakat Desa Banaran dalam rangka membantu menyukseskan progam pemerintah dalam hal pengolahan hasil pertanian. Beberapa hal yang dijadikan dasar adalah:

a. Pengertian partisipasi pembangunan pertanian

1. Partisipasi masyarakat merupakan keikutsertaan, peran serta tau keterlibatan yang berkitan dengan keadaaan lahiriahnya mulai dari tahap sosialisasi, perencanaan, pelaksanaan, dan pelestarian kegiatan dengan memberikan sumbangan tenaga, pikiran, atau dalam bentuk materil.

2. Pembangunan pertanian adalah serangkaian proses yang dengan sengaja di lakukan untuk mencapai tujuan tertentu ke arah yang lebih baik dalam mengembangkan dan meningkatkan sektor pertanian.

3. Paritisipasi dalam sektor pertanian merupakan suatu bentuk partisipasi yang diberikan oleh masyarakat dalam mengembangkan sektor pertanian mulai dari partisipasi tahap sosialisasi, perencanaan, sampai dengan pelaksanaan.

b. Kriteria partisipasi masyarakat

1. Kesempatan, adanya kesempatan yang diberikan pada masyarakat dalam melakukan pembangunan pertanian.

2. Kemauan, adanya kemauan dari masyarakat itu sendiri dalam melakukan partisipasi.

3. Keinginan, adanya keinginan yang kuat dalam melakukan partisipasi sehingga partisipasi dapat berjalan dengan baik.

\section{c. Partisipasi dalam pembangunan pertanian}

1. Dalam perencanaan pembangunan masyarakat bisa langsung berpartisipasi dengan mengeluarkan ide-ide, pikiran, atau saran dalam program kerja yang akan di lakukan ke depan sehingga dapat diambil suatu kebijakan pertanian. Kebijakan pertanian yang dimaksud di sini yaitu bagaimanan nantinya yang akan dilakukan dalam memajukan sektor pertanian. 
2. Dalam pelaksanaan program masyarakat bisa berpartisipasi langsung sehingga dapat diwujudkan suatu tujuan program kerja yaitu terwujudnya sektor pertanian yang tangguh.

3. Dalam evaluasi hasil pelaksanaan program, partisipasi masyarakat yaitu dengan menilai sendiri apakah program yang telah dilaksanakan sebelumnya mengalami keberhasilan atau kegagalan. Artinya di sini masyarakat terjun langsung dalam mengamati hasil program kerja yang telah dilaksanakan.

\section{B. METODE PELAKSANAAN}

Untuk mencapai tujuan yang diharapkan, progam KKN di Desa Banaran di pusatkan di Padukuhan 1 Jati, Bunder 2, dan Bunder 3. Program KKN dilakukan dengan pemberdayaan masyarakat melalui pendidikan masyarakat, difusi ilmu pengetahuan dan teknologi serta praktek langsung. Ringkasan metode pelaksanaan beserta jam kerja efektif mahasiswa (JKEM) tersaji pada tabel II.

Tabel II. Metode, Kegiatan, JKEM dan keterlibatan mahasiswa.

\begin{tabular}{|l|l|l|l|l|}
\hline No & \multicolumn{1}{|c|}{ Metode } & \multicolumn{1}{|c|}{ Kegiatan } & \multicolumn{1}{|c|}{ JKEM } & $\begin{array}{l}\text { Jumlah } \\
\text { mahasiswa yang } \\
\text { terlibat }\end{array}$ \\
\hline 1 & $\begin{array}{l}\text { Pendidikan } \\
\text { masyarakat }\end{array}$ & $\begin{array}{l}\text { Menyelenggarakan } \\
\text { penyuluhan pengolahan } \\
\text { hasil pertanian }\end{array}$ & $1 \times 3$ jam & 12 \\
\cline { 3 - 5 } & $\begin{array}{l}\text { Menyelenggarakan } \\
\text { penyuluhan pengolahan } \\
\text { limbah pertanian }\end{array}$ & $1 \times 3$ jam & 12 \\
\hline 2 & Difusi Iptek & $\begin{array}{l}\text { Menyelenggarakan } \\
\text { pelatihan pengolahan } \\
\text { hasil pertanian }\end{array}$ & $1 \times 3$ jam & 27 \\
\cline { 3 - 5 } & $\begin{array}{l}\text { Menyelenggarakan } \\
\text { pelatihan pengolahan } \\
\text { limbah pertanian }\end{array}$ & $1 \times 3$ jam & 27 \\
\hline 3 & Praktek & $\begin{array}{l}\text { Pengolahan limbah } \\
\text { sayuran dan kulit buah }\end{array}$ & $1 \times 3$ jam & 27 \\
\cline { 3 - 5 } & Pengolahan Jerami & $1 \times 3$ jam & 27 \\
\cline { 3 - 5 } & $\begin{array}{l}\text { Peyuluhan dan } \\
\text { pelatihan Nata de Leri. }\end{array}$ & $1 \times 3$ jam & 27 \\
\hline
\end{tabular}

\section{HASIL, PEMBAHASAN DAN DAMPAK}

\section{Profil Desa}

Desa Banaran terletak di Kecamatan Galur Kabupaten Kulon Progo. Desa ini terletak di wilayah paling selatan dan paling timur diantara desa- desa di Kabupaten Kulon Progo. Batas wilayah desa yakni: 
Diterbitkan oleh Lembaga Pengabdian kepada Masyarakat

Universitas Ahmad Dahlan Yogyakarta
a. Barat : Desa Karangsewu
b. Timur : Sungai Progo
c. Utara : Desa Nomporejo dan Kranggan
d. Selatan : Samudera Hindia

Di samping potensi pertanian yang cukup besar sebagaimana dijelaskan pada bagian sebelumnya, masyarakat Desa Banaran juga memiliki potensi peternakan karena hampir semua warga memiliki ternak. Namun demikian, potensi peternakan ini juga menimbulkan permasalahan pencemaran lingkungan. Hal ini disebabkan oleh limbah ternak yang tidak tertangani. Permasalahan tersebut muncul saat musim hujan tiba dimana air hujan membawa material limbah ternak masuk dan meresap ke dalam tanah sehingga mencemari air sumur warga. Ketiadaan saluran drainase yang layak menyebabkan pencemaran limbah ternak tersebut terjadi. Permasalahan masyarakat Banaran yang lain adalah fasilitas pengolahan sampah karena belum optimalnya prasarana pengelolaan sampah desa. Pada beberapa lokasi desa ditemukan tumpukan sampah terutama di lokasi kawasan wisata pantai Trisik. Hal ini karena belum tersedianya fasilitas pengelolaan sampah yang memadai.

\section{Kependudukan}

Jumlah penduduk Desa banaran tahun 2016 berjumlah 5.474 jiwa dengan rincian 2.802 jiwa laki-laki dan 2.674 perempuan. Pedukuhan paling besar jumlah penduduknya adalah pedukuhan Jati dengan jumlah 497 jiwa atau 9,08\% total penduduk keseluruhan dan jumlah penduduk paling sedikit adalah di pedukuhan Kenteng sebesar 387 jiwa atau 7,07\%.

\section{Gambaran Pelaksanaan}

Gambar aktivitas mahasiswa KKN UAD yang dilaksanakan di Desa Banaran, terutama di Pedukuhan 1 Jati, Bunder 2, Bunder 3 dalam program pengolahan hasil pertanian tersaji pada gambar 1, 2 dan 3.
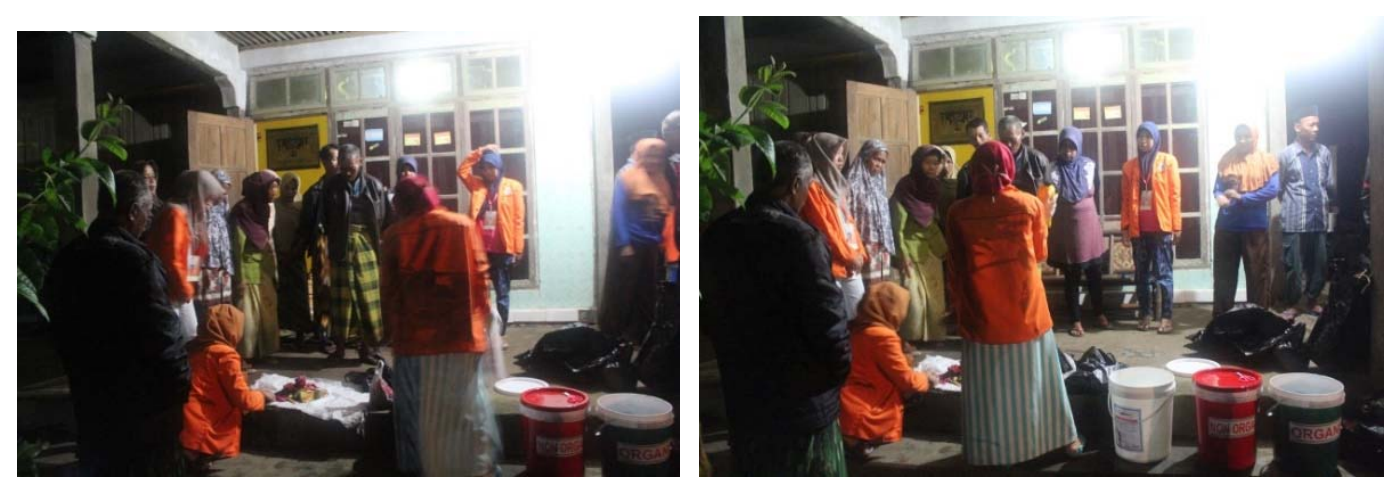

Gambar 1. Pengolahan limbah sayuran dan kulit buah 

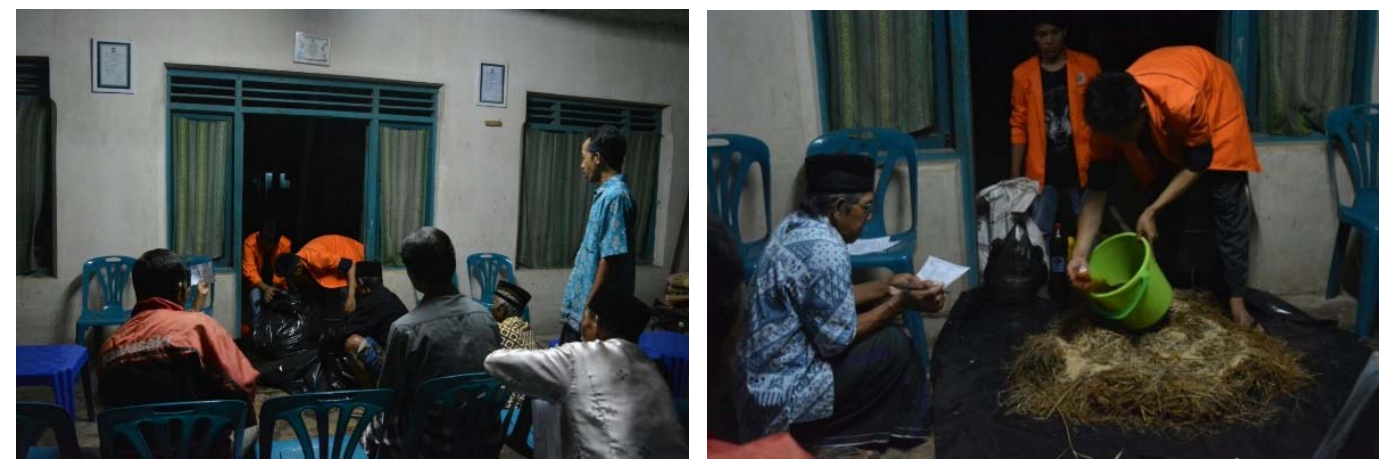

Gambar 2. Pengelolahan jerami
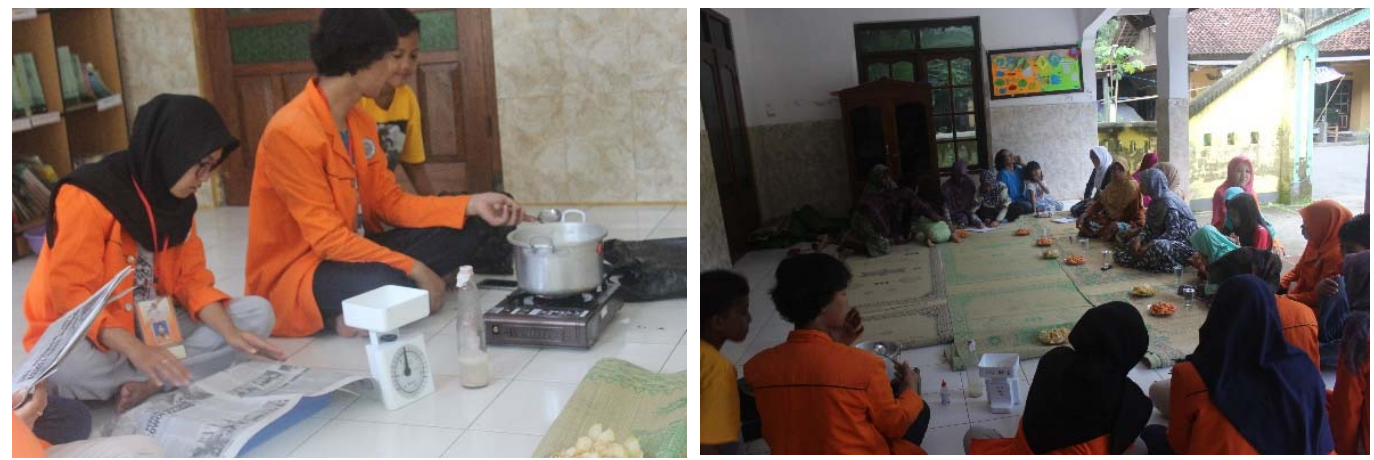

Gambar 3. Pengolahan Nata de Leri

Dari beberapa gambar tersebut tampak bahwa program KKN UAD di Desa Banaran khususnya di pedukuhan 1 Jati, Bunder 2 dan Bunder 3 dapat terlaksana dengan baik dengan partisipasi masyarakat yang cukup tinggi. Dengan kata lain, mahasiswa KKN UAD telah mampu memberdayakan masyarakat Desa Banaran dalam program-program yang telah direncanakan. Dampak dari adanya kegiatan KKN UAD ini adalah:

1. tercipta kesadaran masyarakat sasaran tentang pentingnya pemanfaatan dan pengolahan hasil pertanian

2. peningkatan pengetahuan masyarakat dalam mengolah dan memanfaatkan hasil pertanian

3. masyarakat terampil untuk mengolah potensi hasil dari pertanian dan mengelola limbah yang dihasilkan

\section{KESIMPULAN}

Program KKN UAD dalam memberdayakan masyarakat Desa Banaran khususnya pedukuhan 1 Jati, Bunder 2 dan Bunder 3 terhadap pemanfaatan dan pengolahan hasil pertanian yang telah berjalan dengan baik.

\section{DAFTAR PUSTAKA}

Wahyuningsih, Iis. Dkk. Pemberdayaan Masyarakat Banjar Samiana, Gilimanuk, Bali dalam Program Peduli Lingkungan. Universitas Ahmad Dahlan. UAD

Anonim. Profil Desa Banaran. Menuju Desa Pesisir Indonesia Sejahtera melalui Pengembangan Desa Pesisir Tangguh. Kecamatan Galur. Kulon Progo 